\title{
Aplikasi Pendaftaran Siswa Baru SMA/SMK Provinsi Gorontalo Berbasis Android
}

\author{
Ismail Mohidin, S.Kom, M.T ${ }^{\left.1^{*}\right)}$ \\ Program Studi Teknik Informatika, Politeknik Gorontalo \\ 60111, ${ }^{1 *}$ email : ismailmohidin@poligon.ac.id
}

Saiful Bahri Musa, S.T., M.Kom ${ }^{2 *}$ ), Fadliyanto Badu ${ }^{3)}$

Program Studi Teknik Informatika, Politeknik Gorontalo 60111, email : fadliyanto.mhs15@ti.poligon.ac.id

\begin{abstract}
Setiap tahun ajaran baru terjadi proses penerimaan siswa baru di setiap sekolah yang berada di Provinsi Gorontalo. Proses penerimaan siswa baru pada tahun ajaran 2017-2018 menerapkan aplikasi pendaftaran online penerimaan peserta didik baru berbasis web. Dalam proses tersebut telah mampu mendistribusikan siswa secara proporsional untuk masing-masing sekolah. Namun penerapan aplikasi ini mempunyai beberepa kendala dalam hal proses pendaftaran, karena aplikasi ini membutuhkan komputer yang terkoneksi dengan jaringan internet untuk proses pendaftaran. Sedangkan dibeberapa wilayah Provinsi Gorontalo masih ada yang belum terfasilitasi dengan media computer yang terkoneksi dengan jaringan internet. Oleh karena itu penelitian ini bertujuan untuk membuat sebuah aplikasi pendafataran siswa baru SMA/SMK di Provinsi Gorontalo berbasis android. Aplikasi ini di bangun dengan menggunakan ADT Eclipse dengan bahasa pemrograman java. Dengan aplikasi ini calon siswa baru dapat mengisi form pendaftaran dan melihat informasi berkaitan dengan pendaftaran secara mobile. Aplikasi ini sangat membantu calon siswa baru untuk melakukan pendaftaran menggunakan perangkat mobile. Dimana sebagian besar masyarakat Gorontalo telah menggunakan smartphone. Sehingga masyarakat Gorontalo yang berada di daerah yang tidak terjangkau dengan jaringan internet bisa mengakses aplikasi menggunakan smartphone.
\end{abstract}

Kata kunci : Android, Java, Pendaftaran Peserta Didik Baru, Smartphone.

\section{PENDAHULUAN}

Sistem informasi dimanfaatkan sebagai sarana peningkatan informasi dan pelayanan institusi pemerintah untuk mempermudah suatu pekerjaan seperti dalam pengolahan data dan keputusan yang diambil. Salah satu sistem informasi yang dapat dimanfaatkan adalah proses penerimaan peserta didik baru. Penerimaan Peserta Didik Baru merupakan proses seleksi akademik pada sekolah, hal tersebut berkaitan dengan kemampuan dasar akademik dan minat bakat terhadap jenjang sekolah yang di tuju. Berdasarkan peraturan menteri pendidikan dan kebudayaan Pasal 15-17 Permendikbud Nomor 17 Tahun 2017 tentang Penerimaan Peserta Didik Baru seluruh instansi pemerintah bidang pendidikan seluruh Provinsi wajib melaksanakan proses penerimaan siswa baru untuk setingkat SMA/SMK.
Dengan adanya peraturan Menteri Pendidikan, Provinsi Gorontalo telah menerapkan sebuah aplikasi Penerimaan Peserta Didik Baru (PPDB) berbasis web agar calon siswa mudah mendaftarkan diri serta mendapatkan informasi pendaftaran. Dalam penerapannya, sistem PPDB ini banyak mengalami kendala dalam hal registrasi dibeberapa wilayah terutama yang masih terhitung daerah tertinggal, terpencil dan terluar. Dimana daerah tersebut belum terfasilitasi dengan konektivitas internet, sehingga membuat sebagian calon pendaftar datang ke sekolah yang memiliki fasilitas dan jaringan internet untuk melakukan proses registrasi.

Dengan adanya permasalahan tersebut, penulis membuat "Aplikasi Pendaftaran Siswa Baru SMA/SMK Provinsi Gorontalo Berbasis Android" untuk mempermudah registrasi. Diharapkan dengan adanya aplikasi android ini, para calon siswa akan lebih mudah melakukan registrasi dimana saja. Selain itu, Harganya relatif terjangkau sehingga tidak membebani masyarakat dan orang tua siswa.

\section{METODE PENELITIAN}

\subsection{Waktu dan Tempat Penelitian}

Waktu penelitian yang dilaksanakan, yaitu :

Waktu : Selasa, 28 November 2017

Tempat : SMK N 1 Limboto

\subsection{Alat Dan Bahan}

Tabel 1. Alat dan bahan

\begin{tabular}{lllll}
\hline No. & $\begin{array}{l}\text { Nama Alat dan } \\
\text { Bahan }\end{array}$ & Keterangan & & \\
\hline 1. & Laptop Acer & Processor Intel Core & i3 \\
& & Memory 4 GB & & \\
2. & Operasi Sistem & Windows 7 & & \\
3. & Database & MySQL & & \\
4. & Development Tool & ADT Eclipse & & \\
\hline
\end{tabular}

\subsection{Gambaran Umum Sistem Yang Sedang Berjalan}

Gambaran umum aplikasi web pendaftaran peserta didik baru online Provinsi Gorontalo pada Gambar 1 berikut ini : 


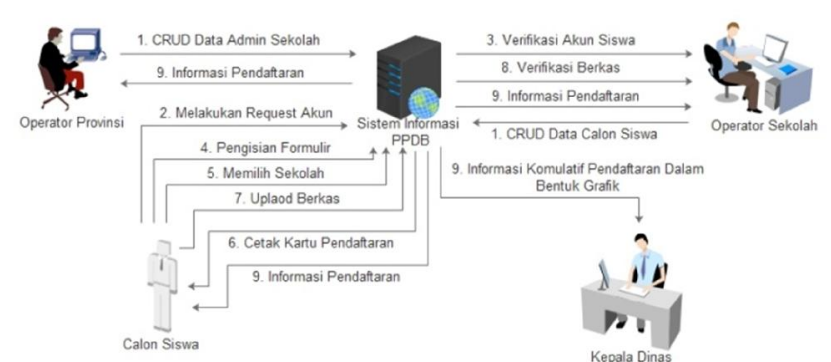

Gambar 1. Gambaran umum sistem yang sedang berjalan Deskripsi dari Gambar 1 adalah sebagai berikut ini :

1. Operator Provinsi menginputkan data ke dalam sistem dan dapat menerima informasi pendaftaran peserta didik baru.

2. Calon siswa melakukan request akun agar bisa mendaftarkan diri ke dalam sistem, mengisi formulir sesuai prosedur yang telah disediakan, dan mencetak kartu pendaftaran jika sudah dinyatakan lulus dari sekolah yang dituju.

3. Operator Sekolah melakukan verifikasi akun, berkas, dan mengelola data peserta didik.

4. Informasi pendaftaran yang di terima berupa hasil dari proses pendaftaran, data pendaftar dan pengumuman sekolah.

\subsection{Perancangan Sistem}

Alur Sistem Yang Diusulkan

Alur aplikasi pendaftaran online setingkat SMK/SMA di Provinsi Gorontalo di mana para calon siswa harus mengikuti proses pendaftaran agar bisa terdaftar di sekolah terdekat. Lihat pada Gambar 2 berikut ini:

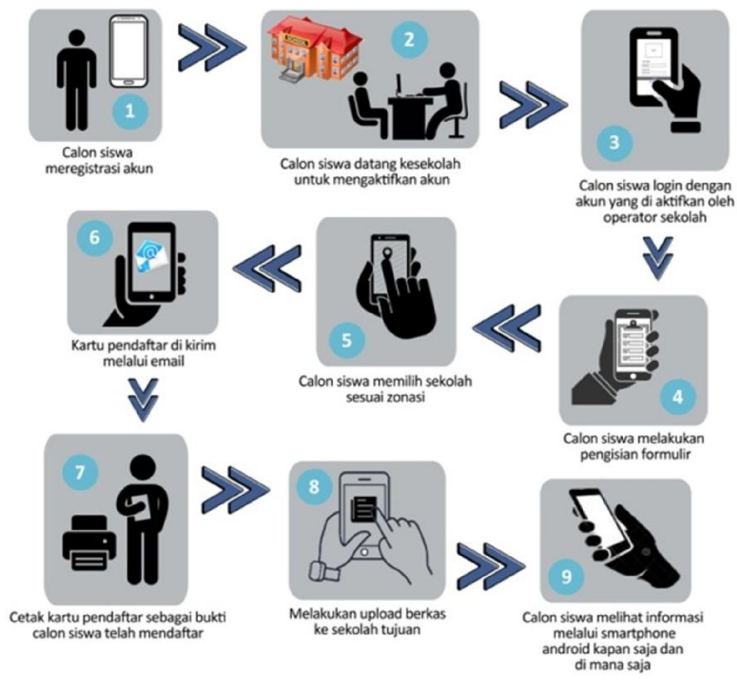

Gambar 2. Alur sistem yang diusulkan

Deskripsi dari Gambar 2 adalah sebagai berikut :

1. Sebelum calon siswa melakukan pendaftaran, calon siswa harus meregistrasi akun terlebih dahulu.
2. Calon siswa datang ke sekolah terdekat untuk mengaktifkan akun dengan tujuan agar akun yang sudah diregistrasi bisa dipakai.

3. Calon siswa login dengan akun yang sudah diaktifkan oleh operator sekolah.

4. Calon siswa melakukan pengisian formulir pendaftaran

5. Calon siswa memilih sekolah yang dituju sesuai zonasi atau memilih sekolah terdekat yang ada dilingkungan tempat tinggal calon siswa.

6. Kartu pendaftaran akan dikirim di email calon siswa setelah melakukan pendaftaran.

7. Cetak kartu pendaftaran yang telah dikirim melalui email calon siswa sebagai bukti bahwa calon siswa telah melakukan pendaftaran.

8. Upload berkas ke sekolah yang dituju untuk melengkapi pendaftaran.

9. Calon siswa melihat informasi melalui smartphone android mengenai hasil pendaftaran atau pengumuman.

$$
\text { Use Case }
$$

Use Case pada gambar 2 berikut merupakan uraian antar muka (Use Interface) atau gambaran kegiatan yang akan dilakukan oleh calon siswa pada aplikasi pendaftaran online berbasis android.

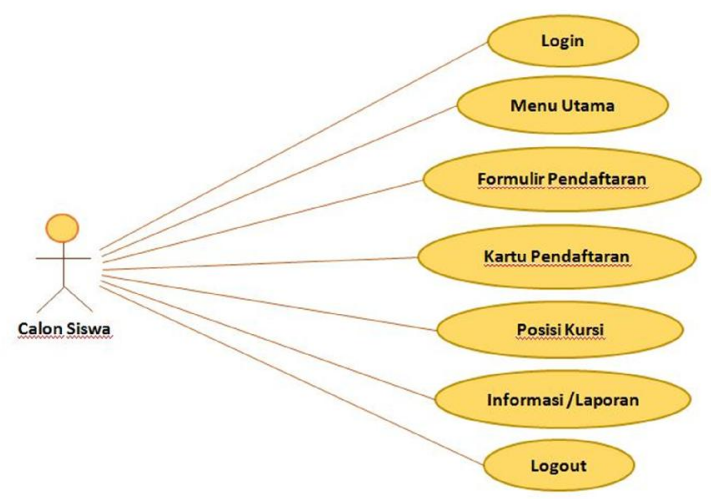

Gambar 3. Use Case Rancangan Sistem

Pada saat calon siswa menjalankan aplikasi, calon siswa login terlebih dahulu sebelum melakukan pendaftaran. Calon siswa harus mengisi formulir pendaftaran sesuai prosedur yang telah disediakan. Setelah formulir dilengkapi calon siswa mengecek posisi kursi untuk mengetahui posisi kursi kelulusan, jika posisi kursi diurutan paling bawah akan ada pemberitahuan memilih sekolah pilihan kedua. Kartu pendaftaran dikirim melalui email yang sudah didaftarkan. Cetak kartu pendaftaran sebagai bukti pendaftaran. Kemudian lihat informasi tentang sekolah yang anda pilih, lakukan logout akun jika semua sudah selesai.

Activity Diagram Kirim Data Pendaftaran

Activity Diagram kirim Data Pendaftaran menjelaskan alur kerja aktor calon siswa baru untuk mengirim data form pendaftaran melalui aplikasi android. 


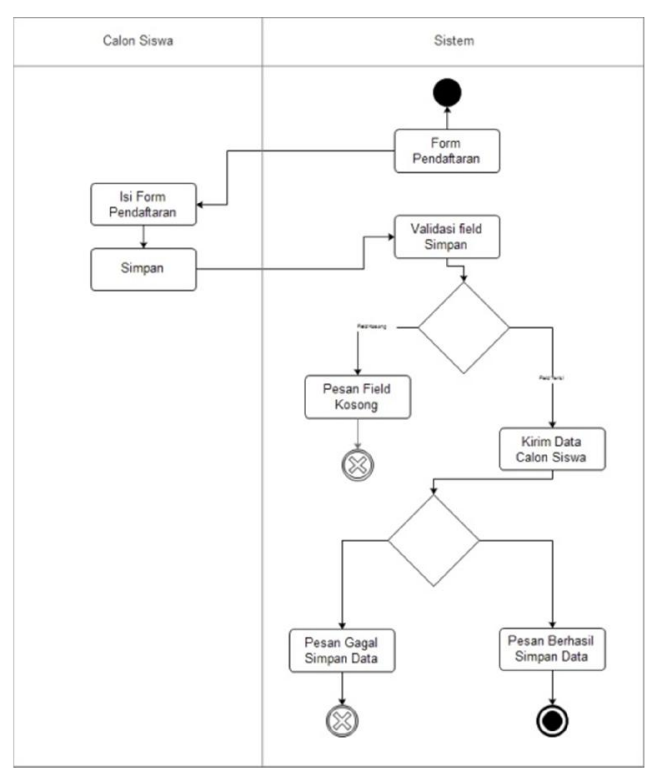

Gambar 5. Activity Diagram Kirim Data Form Pendaftaran

Sequence Diagram Aktor Calon Siswa

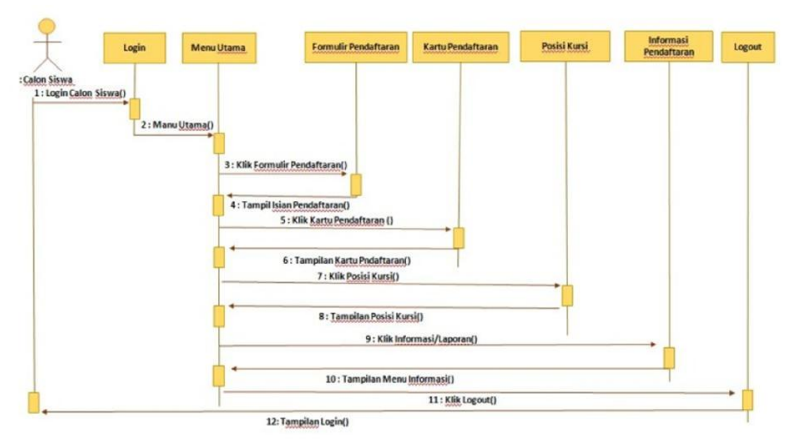

Gambar 4. Sequence Diagram Aktor Calon Siswa

Tabel 6. Deskripsi Sequence Diagram Aktor Calon Siswa

\begin{tabular}{|c|c|}
\hline $\begin{array}{c}\text { Nama } \\
\text { sequence }\end{array}$ & \multicolumn{1}{|c|}{ Fungsi sequence } \\
\hline $\begin{array}{c}\text { Calon Siswa } \\
\text { Siswa Calon }\end{array}$ & $\begin{array}{l}\text { - Calon Siswa disini adalah sebagai } \\
\text { pengguna pada Aplikasi Pendaftaran. } \\
\text { - Calon siswa melakukan login untuk } \\
\text { dapat mengakses system. }\end{array}$ \\
\hline Menu Utama & - Menampilkan form menu utama. \\
\hline $\begin{array}{c}\text { Form } \\
\text { Pendaftaran }\end{array}$ & $\begin{array}{l}\text { - Merupakan proses menambahkan } \\
\text { data Calon Siswa Baru ke dalam basis } \\
\text { data melalui aplikasi di perangkat } \\
\text { mobile. }\end{array}$ \\
\hline $\begin{array}{c}\text { Kartu } \\
\text { Pendaftaran }\end{array}$ & $\begin{array}{l}\text { Kartu pendaftaran akan di kirim ke } \\
\text { email, dan download untuk mencetak. }\end{array}$ \\
\hline
\end{tabular}

\begin{tabular}{|c|l|}
\hline Posisi Kursi & $\begin{array}{l}\text { Melihat posisi kursi kelulusan calon } \\
\text { siswa. }\end{array}$ \\
\hline $\begin{array}{c}\text { Data } \\
\text { Informasi }\end{array}$ & $\begin{array}{l}\text { - Proses menampilkan seluruh data info } \\
\text { pengumuman yang masih memiliki } \\
\text { status aktif dari basis data sistem. }\end{array}$ \\
\hline Logout & $\begin{array}{l}\text { - Keluar dari sistem dan kembali ke } \\
\text { form login. }\end{array}$ \\
\hline
\end{tabular}

\section{Desain Database}

Gambar dibawah merupakan desain database aplikasi yang akan dibuat, desain database memiliki beberapa tabel yang akan digunakan. Tabel pada gambar dibawah memiliki beberapa atribut atau field yang akan digunakan.

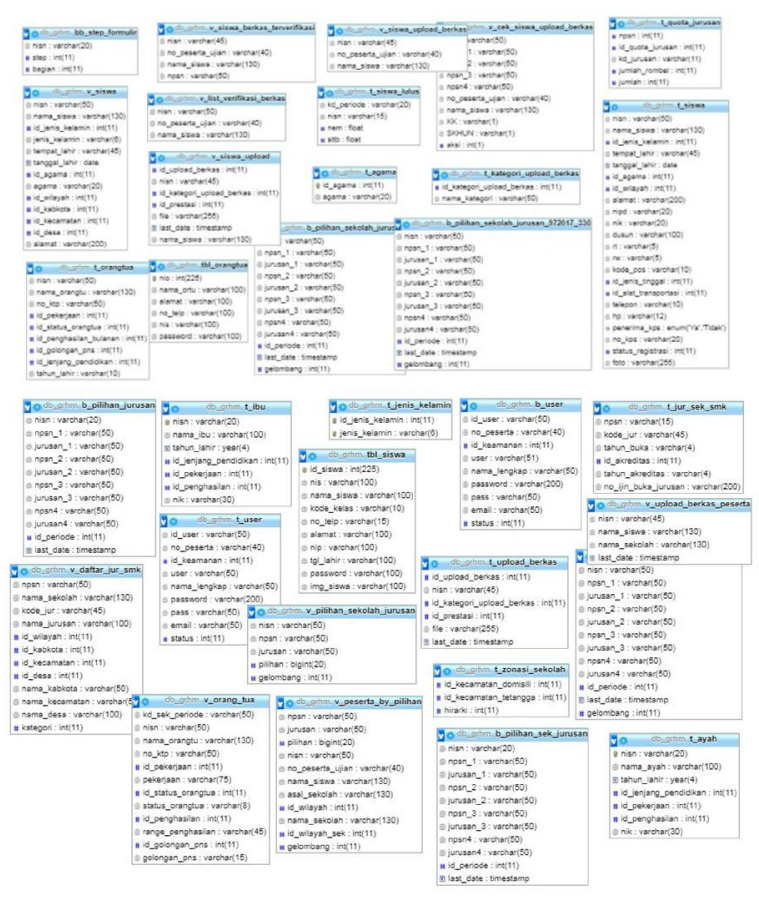

Desain Aplikasi

Tampilan aplikasi Android pada pendaftaran siswa ketika berhadapan dengan pengguna.

Rancangan Menu Tampilan Utama

Tampilan awal ketika aplikasi di jalankan.

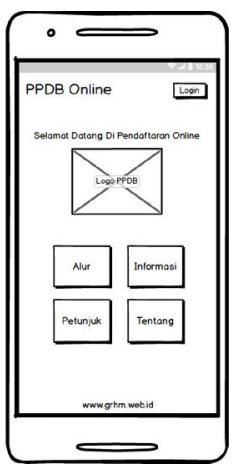

Gambar 6. Rancangan Tampilan Utama

ISSN : 2502-1613 
Rancangan Tampilan Form Login

Login peserta didik agar bisa melakukan pendaftaran, jika bulum punya akun lakukan registrasi akun.

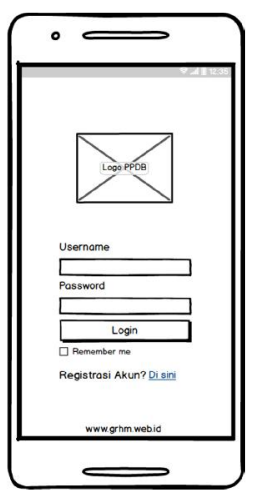

Gambar 7. Rancangan Tampilan Login

Rancangan Tampilan Registrasi Akun

Tampilan untuk mendaftarkan akun peserta agar dapat masuk kedalam sistem pendaftaran online.

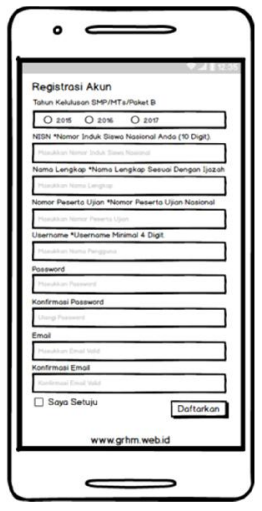

Gambar 8. Rancangan Registrasi Akun

Rancangan Tampilan Isi Form Pendaftaran Data Diri Tampilan di mana peserta akan melakukan inputan untuk data diri peserta.

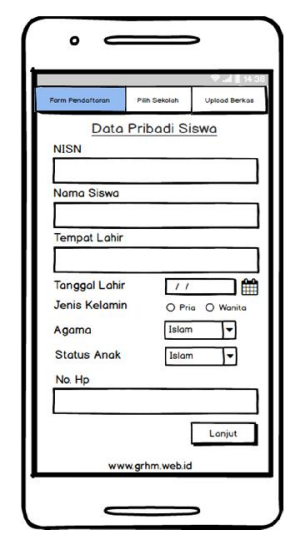

Gambar 9. Form Pendaftaran Input Data Diri
Rancangan Tampilan Isi Form Pendaftaran Keterangan Form pendaftaran pengimputan tempat tinggal peserta.

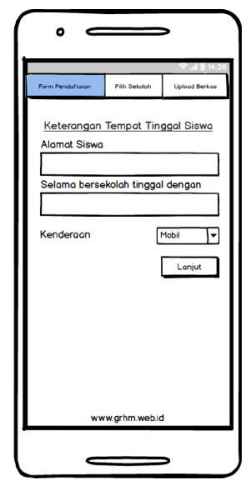

Gambar 10. Form Pendaftaran Input Tempat Tinggal

Rancangan Tampilan Isi Form Pendaftaran Keterangan Jasmani

Tampilan dimana peserta melakukan inputan keterangan jasmani dari peserta.

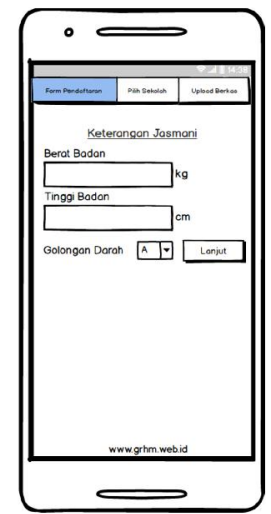

Gambar 11. Form Pendaftaran Input Keterangan Jasmani

Rancangan Tampilan Isi Form Pendaftaran Keterangan Pendidikan

Pada tampilan ini peserta menginput pendidikan sebelumnya

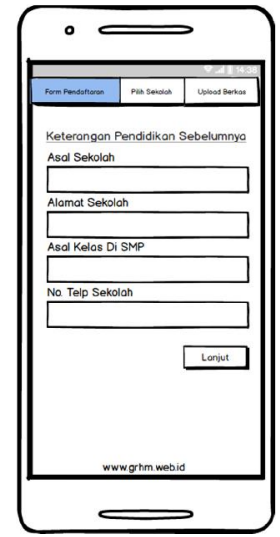

Gambar 12. Form Pendaftaran Input Keterangan Pendidikan

ISSN : 2502-1613 
Rancangan Tampilan Isi Form Pendaftaran Keterangan Orang Tua

Pada tampilan ini peserta melakukan inputan data orang tua dari peserta didik.

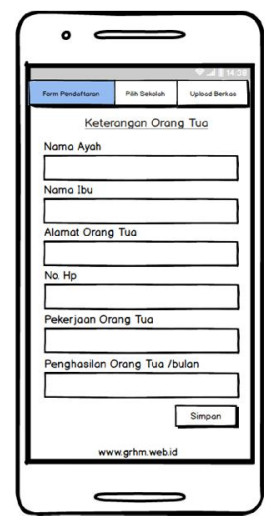

Gambar 13. Form Pendaftaran Input Keterangan Orang Tua

Rancangan Tampilan Memilih Sekolah

Pada tampilan ini peserta memilih sekolah mana yang diminat

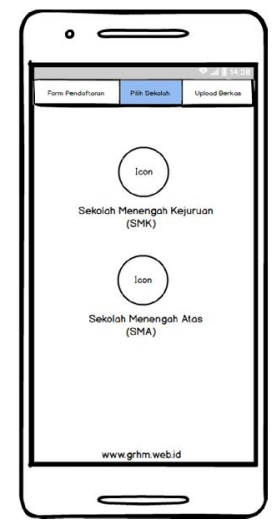

Gambar 14. Rancangan Tampilan Pilih Sekolah

Rancangan Tampilan Pilih Sekolah SMK

Pemilihan sekolah SMK ini akan tampil ketika peserta memilih sekolah SMK.

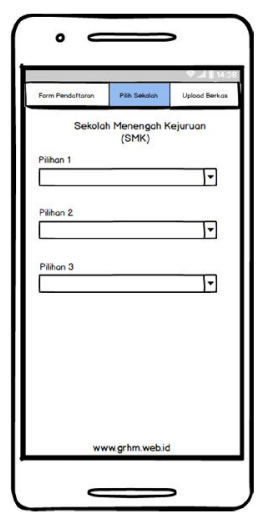

Gambar 15. Rancangan Tampilan Memilih Sekolah SMK

Rancangan Tampil Pilih Sekolah SMA

Pemilihan sekolah SMA ini akan tampil ketika peserta memilih sekolah SMA.

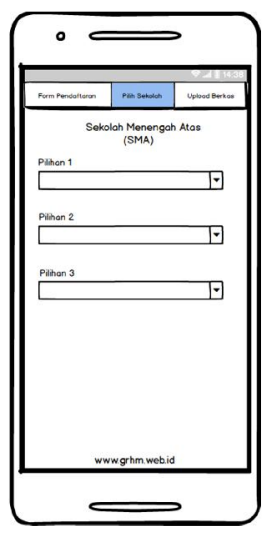

Gambar 16. Rancangan Tampilan Memilih Sekolah SMA

Rancangan Tampilan Upload Berkas

Tampilan dimana peserta melakukan upload berkas sebagai persyaratan.

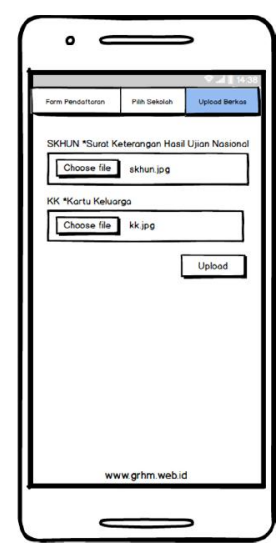

Gambar 17. Rancangan Tampilan Upload Berkas

Rancangan Tampilan Alur Pendaftaran

Tampilan yang memuat informasi tentang bagaimana alur untuk pendaftaran.

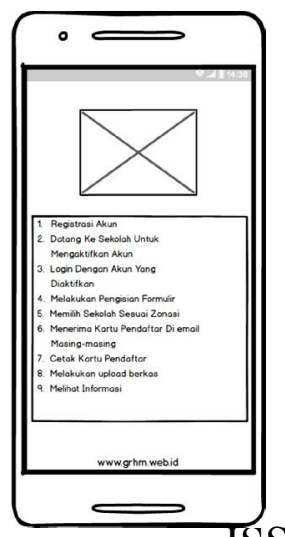


Gambar 18. Rancangan Tampilan Alur Pendaftaran Rancangan Tampilan Informasi Menampilkan Data Peserta

Tampilan ini akan menampilkan informasi bagi data peserta yang mendaftar

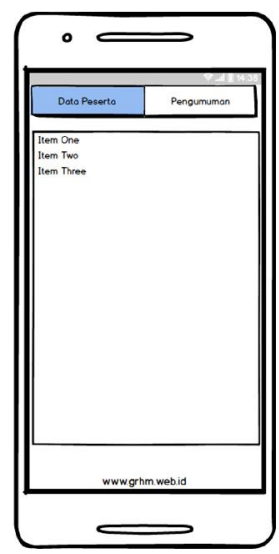

Gambar 19. Rancangan Tampilan Data Pendaftar

Rancangan Tampilan Informasi Pengumuman

Tampilan ini akan menampilkan informasi-informasi dari admin sekolah

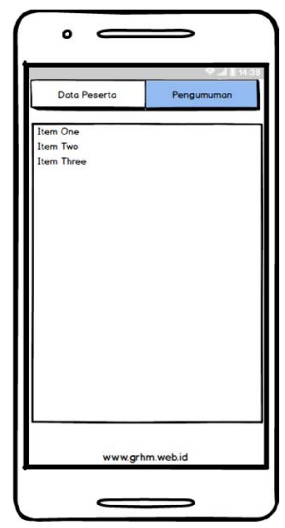

Gambar 20. Rancangan Tampilan Pengumuman

Rancangan Tampilan Petunjuk Pendaftaran

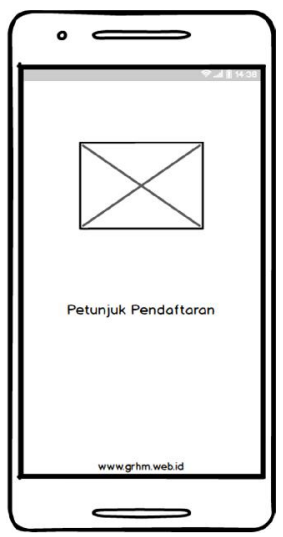

\section{Gambar 21. Rancangan Tampilan Petunjuk Pendaftaran}

\section{IMPLEMENTASI}

Pada bagian ini penulis akan mengimplementasikan hasil dari penelitian yang penulis teliti selama beberapa bulan sehingga pada tahap ini dapat dilihat bagaimana sistem yang dibuat beroperasi. Sebelum melangkah pada tahap pendaftaran siswa kita harus login terlebih dahulu.

Tampilan Login

Login merupakan proses masuk bagi pengguna dengan memasukkan identitas akun minimal terdiri dari username/akun pengguna dan password untuk mendapatkan hak akses. Pengguna yang sudah login bisa langsung melakukan pengisian formulir peserta.

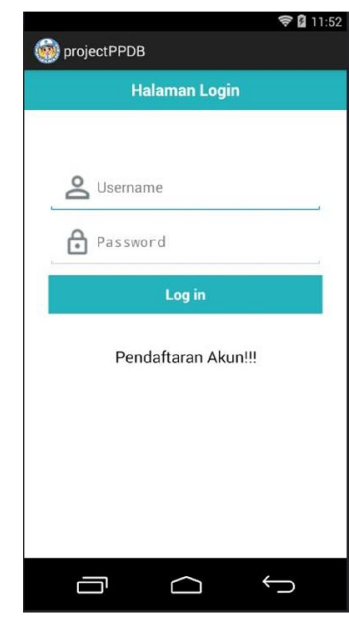

Gambar 22. Tampilan Login

Tampilan Registrasi

Sebelum melakukan login, peserta didik harus melakukan registrasi yang merupakan urutan prosedur pendaftaran yang wajib dijalani oleh setiap Calon siswa/i baru. Registrasi dilakukan dengan mengisi beberapa kolom seperti gambar dibawah. Registrasi bertujuan untuk mendapatkan akun login ke sistem Pendaftaran Online Siswa Baru.

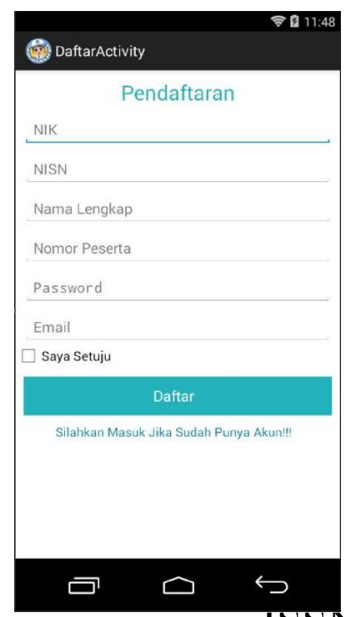

ISSN : 2502-1613 
Gambar 23. Tampilan Registrasi

Tampilan Menu Home

Menu home adalah halaman utama atau bagian depan dari aplikasi yang berisi menu-menu dari aplikasi penerimaan siswa baru. Tampilan home terdapat beberapa menu yaitu formulir, kartu, dan posisi kursi.

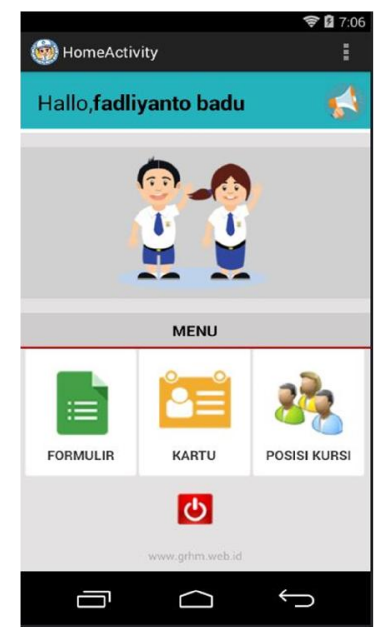

Gambar 24. Tampilan Menu Home

Tampilan Pengisian Formulir

Untuk melakukan pendaftaran secara online, calon siswa wajib mengisi formulir data diri, data orang tua, dan pilihan sekolah yang diminati. Semua informasi atau data yang dimasukkan dalam formulir pendaftaran harus berdasarkan dokumen asli secara benar. Data yang sudah dilengkapi dengan benar dapat di upload pada menu upload berkas.

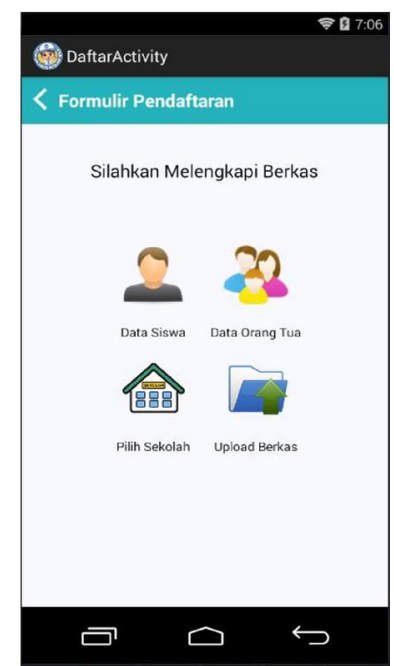

Gambar 25. Tampilan Pengisian Formulir

Tampilan Pengisian Data Siswa Step 1

Pengisian data siswa ini bertujuan untuk kelengkapan data siswa baru dengan mengisi beberapa kolom pada gambar dibawah ini dengan baik dan benar.

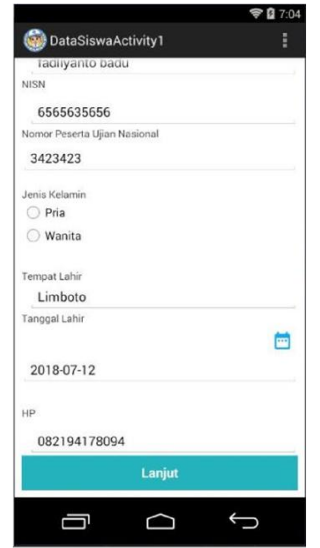

Gambar 26. Tampilan Pengisian Data Siswa Step 1

Tampilan Pengisian Data Siswa Step 2

Setelah melakukan pengisian data siswa step 1 dilanjutkan dengan pengisian data siswa step 2. Pada pengisian data siswa step kedua ini merupakan pengisian data mengenai alamat lengkap calon siswa yang ingin melakukan pendaftaran.

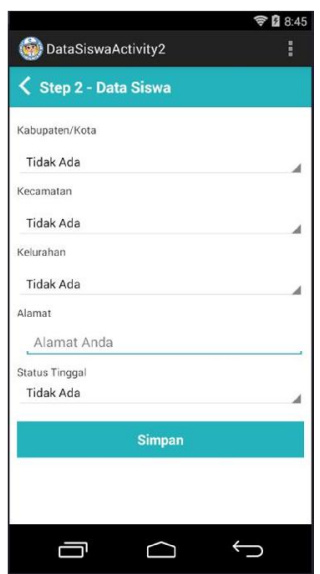

Gambar 27. Tampilan Pengisian Data Siswa Step 2

Tampilan Pengisian Data Orang Tua

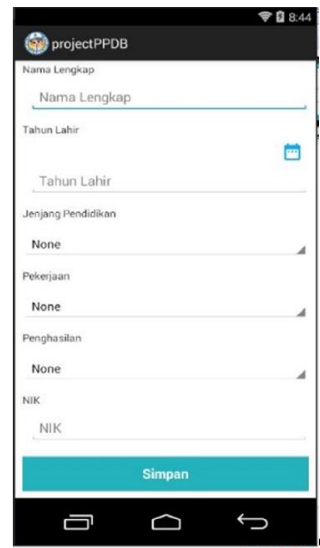


Gambar 28. Tampilan Pengisian Data Orang Tua

Data orang tua yang dimasukkan harus sesuai dengan data yang ada. Data yang dilengkapi berupa nama lengkap, jenjang pendidikan, pekerjaan, dan penghasilan perbulan.

\section{Tampilan Pilihan Sekolah}

Ada dua jenis sekolah menengah yang dapat dimasuki yaitu sekolah menengah umum (SMA) dan sekolah menengah kejuruan (SMK).

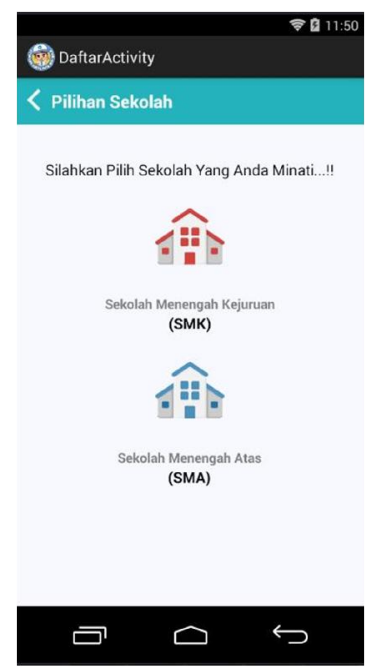

Gambar 29. Tampilan Pilihan Sekolah

Tampilan Form Pilih Sekolah SMK

Setelah melakukan pemilihan sekolah, calon siswa baru wajib memilih jurusan yang diminati sesuai jurusan yang ada disekolah yang dipilih.

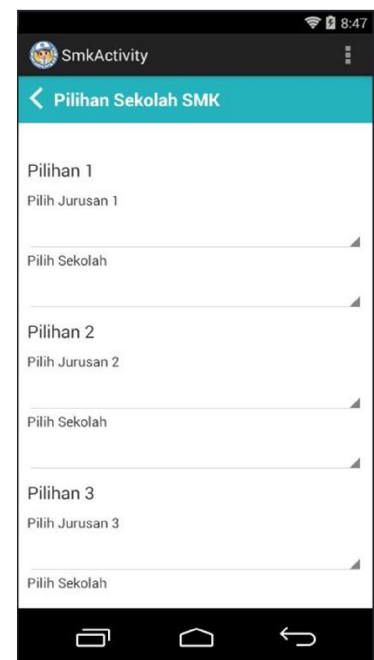

Gambar 30. Tampilan Form Pilih Sekolah SMK

Tampilan Form Pilih Sekolah SMA
Calon siswa memasukkan tiga pilihan sekolah yang diminati dan menjadi tujuan calon siswa.

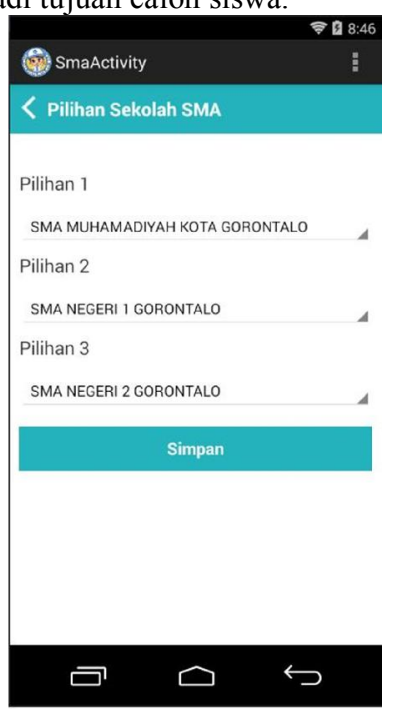

Gambar 31. Tampilan Form Pilih Sekolah SMA

Tampilan Upload Berkas

Setelah melakukan tahap-tahap pendaftaran, calon siswa harus melengkapi berkas sebagai bukti bahwa data yang dimasukkan benar-benar data siswa itu sendiri. Berkas yang di upload harus dengan format file PNG atau JPG. Berkas berupa kartu keluarga dan kartu Indonesia sehat (KIS).

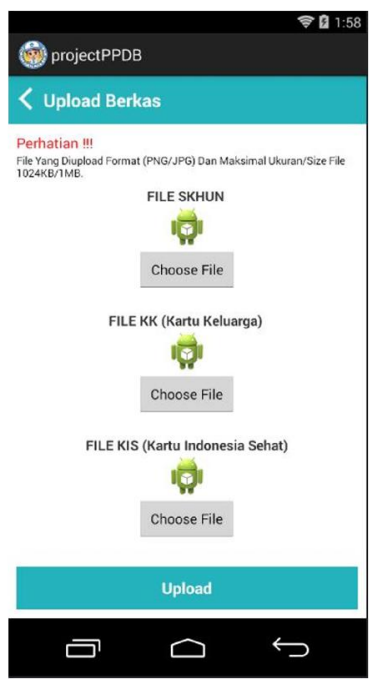

Gambar 32. Tampilan Upload Berkas

\section{KESIMPULAN}

Setelah melakukan analisis pada aplikasi pendaftaran siswa baru SMA/SMK provinsi gorontalo, maka dapat disimpulkan bahwa sistem pendaftaran online mampu membuat proses pendaftaran siswa menjadi lebih mudah dan cepat. Calon siswa dapat mendaftar dimana saja, kapan saja

ISSN : 2502-1613 
dengan aplikasi ini dan dapat menghasilkan informasi lebih cepat.

\section{SARAN}

Dengan memperhatikan masalah-masalah yang dihadapi dalam pembuatan aplikasi Pendaftaran Siswa Baru SMA / SMK PROVINSI GORONTALO BERBASIS ANDROID. Kami dapat menyarankan antara lain adalah :

1. Agar aplikasi ini dapat dipakai oleh pihak-pihak dari Provinsi Gorontalo untuk membantu bagi para calon siswa SMA / SMK di Provinsi Gorontalo

2. Diharapkan aplikasi ini kedepannya dapat dikembangkan baik dari segi aplikasi ataupun sistem yang ada pada pendaftaran siswa baru SMA / SMK di Provinsi Gorontalo.

\section{DAFTAR PUSTAKA}

[1] Haviluddin. (2011). Memahami Penggunaan UML ( Unified Modelling Language ). Memahami Penggunaan UML (Unified Modelling Language), 6(1), 1-15. https://doi.org/10.1017/CBO9781107415324.004

[2] Ii, B. A. B. (n.d.). KBBI, 1991, 232 Suparlan Suhartono, Filsafat Pendidikan , (Yogyakarta: Ar-Ruzz Media, 2007), 77.

[3] Irsan, M., Studi, P., Informatika, T., Teknik, F., Tanjungpura, U., \& Prof, J. (n.d.). Rancang Bangun Aplikasi Mobile Notifikasi Berbasis Android untuk mendukung kinerja di Instansi pemerintahan.

[4] Ririn Hariyati. (2012). Sistem informasi penerimaan peserta didik baru (ppdb) online berbasis web dan sms.

[5] Wandy Damarullah, Amir Hamzah, U. L. (2013). Jurnal SCRIPT Vol . 1 No . 1 Desember 2013 ISSN : 23386304 Jurnal SCRIPT Vol . 1 No . 1 Desember 2013 ISSN : 2338-6304, 1(1), 78-88. 